\title{
Article \\ Calibration of Thermal Dissipation Probes for Date Palm (Phoenix dactylifera L.)
}

\author{
Fouzia Alla ${ }^{1, *} \mathbb{0}$, Kawtar Jdaini ${ }^{1}$, Hanane M'hamdi $^{1}$, Hamza Mechchate ${ }^{2, *} \mathbb{0}$, Mashail N. AlZain ${ }^{3}$, \\ Nurah M. Alzamel ${ }^{4}\left(\mathbb{D}\right.$, Omar Noman $^{5}$, Jamal Mimouni ${ }^{6}$ and Mohammed Aziz Elhoumaizi ${ }^{1}$ (D)
}

1 Laboratory of Agricultural Production Improvement, Biotechnology and Environment (LAPABE), Faculty of Sciences, University Mohammed First, Oujda 60000, Morocco; k.jdaini@ump.ac.ma (K.J.); h.mhamdi@ump.ac.ma (H.M.); m.elhoumaizi@ump.ac.ma (M.A.E.)

2 Department of Chemistry, University of Helsinki, A.I. Virtasenaukio 1, 00560 Helsinki, Finland

3 Department of Biology, College of Sciences, Princess Nourah Bint Abdulrahman University, P.O. Box 84428, Riyadh 11671, Saudi Arabia; mnalzain@pnu.edu.sa

4 Department of Biology, College of Science and Humanities, Shaqra University, Shaqra 11961, Saudi Arabia; nalzamel@su.edu.sa

5 Department of Pharmacognosy, College of Pharmacy, King Saud University, Riyadh 11451, Saudi Arabia; onoman20@gmail.com

6 National Agency for the Development of Oasis and Argan Areas (ANDZOA), Bouarfa 61200, Morocco; mimounijamal@gmail.com

* Correspondence: f.alla@ump.ac.ma (F.A.); Hamza.mechchate@helsinki.fi (H.M.)

Citation: Alla, F.; Jdaini, K.; M'hamdi, H.; Mechchate, H.; AlZain, M.N.; Alzamel, N.M.; Noman, O.; Mimouni, J.; Elhoumaizi, M.A. Calibration of Thermal Dissipation Probes for Date Palm (Phoenix dactylifera L.).

Horticulturae 2022, 8, 107. https:// doi.org/10.3390/horticulturae8020107

Academic Editors: Jérémie Santini, Julie Oustric-Matelli and Radia Lourkisti

Received: 22 December 2021

Accepted: 19 January 2022

Published: 25 January 2022

Publisher's Note: MDPI stays neutral with regard to jurisdictional claims in published maps and institutional affiliations.

Copyright: (C) 2022 by the authors. Licensee MDPI, Basel, Switzerland. This article is an open access article distributed under the terms and conditions of the Creative Commons Attribution (CC BY) license (https:// creativecommons.org/licenses/by/ $4.0 /)$.

\begin{abstract}
The quantification of water flow through the stem is vital for date palm (Phoenix dactylifera L.) to promote a good water stress management. The thermal dissipation probe (TDP) method developed by Granier is widely used to evaluate transpiration of forest trees; however, there are contradictory reports regarding its reliability. Considerable errors in estimated sap flux density, which might be due to a lack ofspecies-specific calibrations. The TDP method uses a mathematical model that is based on an empirical equation to estimate sap flux density, which is claimed to be applicable to all tree species, independently of wood structure and anatomy. At the laboratory, we compared the rate of water uptake by cut stems with sap flux estimates derived from the TDP method to assess the validity of the method.Our calibration results were considerably different compared to the Granier's original equation. Moreover, sap flux density was overestimated by $18.2 \pm 0.5 \%$ when the original calibration parameters of Granierare employed. However, using new calibration parameters improved the accuracy of sap flow measurements. Our results indicated that it is not appropriate to use a general equation for different species. Therefore, previous estimations of date palm's water requirement through thermal dissipation probes should be revised.
\end{abstract}

Keywords: Phoenix dactylifera L.; water requirement; sap flow; Granier; calibration; transpiration; thermal dissipation probes

\section{Introduction}

Date palm (Phoenix dactylifera L.) is the principal horticultural crop in the arid and semi-arid regions [1]. In Morocco, the annual average production of date palm is about 82,440 t (1997-2017) [2]. The date palm plays an integral role on economic, ecological and social plans. It is one of the most important commercial crops, and it is the main source of income of oases inhabitants [3]. Despite its environmental and socioeconomic importance, knowledge about the real water requirements of date palms in Morocco remains limited, and the few available studies about palm water management are based mostly on climatic, or soil water data approaches [4].

Several methods have been developed to estimate plant transpiration rate [5]. Sap flow techniques remain the most widely accepted [6]. These techniques include thermal dissipation probes [7,8], heat field deformation [9], heat pulse velocity $[10,11]$, and heat 
balance $[12,13]$. They all use heat as a tracer for sap flux estimates, and they differ in terms of cost, plant species, and size of a plant stem [5].

Granier's [7] thermal dissipation probes method (TDP) is a commonly used method to estimate sap flux density, due to it being easy to install, and it allows continuous long-term estimates of sap flow $[14,15]$. Additionally, it provides a low-heat power, which causes less destruction to the xylem tissue $[16,17]$. Nevertheless, estimating sap flux density can produced large errors $[18,19]$. The main sources of errors are related to the sensor type [20], wound effects [21], the wood properties [20,22], the wrong positioning of the probes in non-conductive tissue [23], probe misalignment [24], sensor length [25], and the absence of species-specific calibration parameters [26,27].

The first calibration of the TDP method [7] on three various tree species (Pinus nigra, Pseudotsuga menziesii, and Quercus pedunculata) indicated the independence of wood properties regardless of stem size or xylem anatomy [20]. In fact, many studies adopted the initial calibration of the TDP method [25,28,29]. However, Fabrício et al. [30], Niu et al. [31], and Sun et al. [14] reported that the original parameter values significantly underestimated sap flux. Steppe et al. [19] concluded that the first calibration of Granier is not appropriate for all the species, and that species-specific parameter values may be required, as was reported by Smith and Allen [5].

Indeed, new calibration parameter values have been applied on different tree species, especially in dicotyledonous species. Calibrations has been performedon kiwifruit (Actinidia deliciosa) [32], papaya (Carica papaya) [30], pear (Pyrus communis) [33], mango (Mangifera indica), rubber tree (Hevea brasiliensis) and grapefruit (Citrus maxima) [34], tamarisk (Tamarix spp.) [16], American beech (Fagus grandifolia) [19], orange valencia (Citrus sinensis) [35], bamboo (Bumbusa chungii) [36], apple (Malus domestica), nectarine (Prunus persica), persimmon (Diospyros kaki) [37], corn (Zea mays), sunflower (Helianthus annuus) [38], citrus (Citrus spp.) [39], and Eucalyptus (Eucalyptus grandis $\times$ urophylla) [40,41].

Concerning palms, calibration of the TDP method has been applied on coconut palm (Cocos nucifera) [42], Amazonian palm (Iriartea deltoidea) [43], and recently on oil palm (Elaeis guineesis Jacq.) [31]. All available studies on date palm's wateruse characteristics measured by TDP method [44,45], were based only on original Granier calibration [7] and on Renninger modified calibration [43]. The aim of this study was to assess the applicability of the original calibration equation reported by Granier [7], and if it is necessary to generate new specific parameters for date palm trees.

\section{Materials and Methods}

\subsection{Study Area}

The study area is located in the Figuig oasis, located in the Southeast of Morocco. The climate is arid with an annual mean temperature of $32{ }^{\circ} \mathrm{C}$ and annual mean precipitation of $92.4 \mathrm{~mm}$ (2009-2019).Following the USDA Soil Textural Triangle, the study area soil was sandy loam with $71.1 \%$ sand, $12.5 \%, 27.8 \%$, and $1.1 \%$ clay in the upper $1.5 \mathrm{~m}$. The soil average field capacity and the average bulk density were $25 \%$, and $1.18 \mathrm{~g} / \mathrm{cm}^{3}$, respectively. Mean soil $\mathrm{pH}$ was moderately alkaline (8.4). The soil was characterized by low phosphorus concentration $(<0.01)$, and micro-nutrients $(\mathrm{Cu}, \mathrm{Fe}, \mathrm{Mn}, \mathrm{Zn}, \mathrm{B} ;<0.01)$. The concentration of the mineral profile: $\mathrm{CaCO}_{3}, \mathrm{~K}_{2} \mathrm{O}, \mathrm{MgO}$, and $\mathrm{Na}_{2} \mathrm{O}$ was high with $19.4 \%$, and 237.3, 340, $1854.7 \mathrm{mg} / \mathrm{kg}$, respectively. The soil was also categorized as soil with a low percentage of organic matter $(0.3 \%)$. Date palm represents the main crop in this region and covers about 1280 ha, of which 780 ha are located in the traditional oasis. 'Assiane', 'Boufeggous', and 'Khalt' represent the main cultivars of date palm (58\% for 'Assiane', 28.70\% for 'Boufeggous' and $13.60 \%$ for 'Khalt'). Two water management models characterized this oasis as a traditional system inside the old plantations and drip system for the modern plantations.

\subsection{Plant Material and Sample Preparation}

Calibration experiments were carried with nine cut stem segments from three 15 yearsolddate palm trees (Phoenix dactylifera L., cv. 'Assiane'; 'Tadmament' and 'Khalt') (see 
Supplementary Materials file). Trees without any visible damage, diseases or irregularities in the stem were selected in a plantation inside the oasis $\left(32^{\circ} 05^{\prime} \mathrm{N}\right.$; $01^{\circ} 14^{\prime} \mathrm{E}$; Elevation $881 \mathrm{~m})$. The stems height and the diameter ranged from 2.28 to $3.00 \mathrm{~m}(\mathrm{SD} \pm 0.37 \mathrm{~m})$ and 27 to $31 \mathrm{~cm}(\mathrm{SD} \pm 2.20 \mathrm{~cm})$, respectively.

For each tree, three stem segments of $\sim 40 \mathrm{~cm}$ were cut with a chainsaw. Characteristics of stem segments per each cultivar are presented in Table 1. Subsequently, cut stem were directly submerged in clean water to minimize evaporation and to prevent dehydration. The cut stems were then immediately transported to the laboratory.

Table 1. Properties of stem segments used in the calibration experiment. Circumference and diameter are given as mean \pm standard deviation.

\begin{tabular}{cccc}
\hline Cultivars & Circumference (cm) & Diameter $(\mathbf{c m})$ & $\mathbf{N}^{*}$ \\
\hline 'Assiane' & $86.96 \pm 0.95$ & $27.69 \pm 0.30$ & 3 \\
'Tadmament' & $85.16 \pm 0.76$ & $27.12 \pm 0.24$ & 3 \\
'Khalt' & $94.83 \pm 3.40$ & $30.20 \pm 1.08$ & 3 \\
\hline
\end{tabular}

* The number of cut stem segments per cultivars.

\subsection{Thermal Dissipation Probes Method (TDP)}

The TDP method [7] is based on the temperature differential $(\Delta T)$ between two cylindrical probes inserted radially into the stem, at a spacing of 10-15 cm apart. The upper probe contains a constantan heating element that heats at a constant power $(0.2 \mathrm{~W})$, while the lower probe serves as a temperature reference.

$\Delta T$ is then related to the sap flow density $\left(\mathrm{J}_{\mathrm{s}}, \mathrm{g} \mathrm{m}^{-2} \mathrm{~s}^{-1}\right)$, using Granier's original equation [7]:

$$
\mathrm{J}_{\mathrm{s}}=\alpha \mathrm{K}^{\beta}
$$

where $\alpha=119\left(\mathrm{~g} \mathrm{~m}^{-2} \mathrm{~s}^{-1}\right)$ and $\beta=1.231$ are original fitting coefficients [7], and $\mathrm{K}$ is a dimensionless value:

$$
\mathrm{K}=\frac{\Delta \operatorname{Tmax}-\Delta T}{\Delta T}
$$

where $\Delta \operatorname{Tmax}\left({ }^{\circ} \mathrm{C}\right)$ is the temperature difference between the two probes under zero flux, and $\Delta T\left({ }^{\circ} \mathrm{C}\right)$ is the temperature difference at time $t$.

Total sap flux $\left(\mathrm{F}_{\mathrm{s}}, \mathrm{m}^{3} \mathrm{~s}^{-1}\right)$ can be calculated by multiplying the sap flow density $\left(\mathrm{J}_{\mathrm{s}}\right)$, by the sapwood area (SA) [7]:

$$
\mathrm{F}_{\mathrm{S}}=\mathrm{J}_{\mathrm{S}} \times \mathrm{SA}
$$

where $F_{\mathrm{S}}$ is the total sap flow $\left(\mathrm{m}^{3} \mathrm{~s}^{-1}\right)$, and SA is the cross-sectional area of sapwood $\left(\mathrm{m}^{2}\right)$.

\subsection{Laboratory Calibration}

In the laboratory, both ends of each cut stem segments were re-cut and the vessels blocked were completely opened using a sharp razor blade, then each stem segment's base end was immersed in a container filled with demineralized water with $20 \mathrm{mM} \mathrm{KCl}$ to decrease hydraulic resistance. A $2 \mathrm{~cm}$ wide wood strip was removed at the top of each stem segments to facilitate the installation of an acrylic plate. The airtightness between the plate and stem segment surface was achieved by applying a sealant, rubber gaskets, and hose clamps. Plastic tubing in the center of the plate was linked to a vacuum pump via a $2 \mathrm{~L}$ Erlenmeyer vacuum flask (Figure 1 ). Every $2 \mathrm{~min}$, a gravimetric measurement $\left(\mathrm{J}_{\mathrm{g}}\right)$ was taken by weighing the water pumped through the cut segments (accuracy of electronic balance: $0.01 \mathrm{~g}$ ). The described experimental setup was previously tested to study the effect of wound formation on measuring sap flow density [26]. 


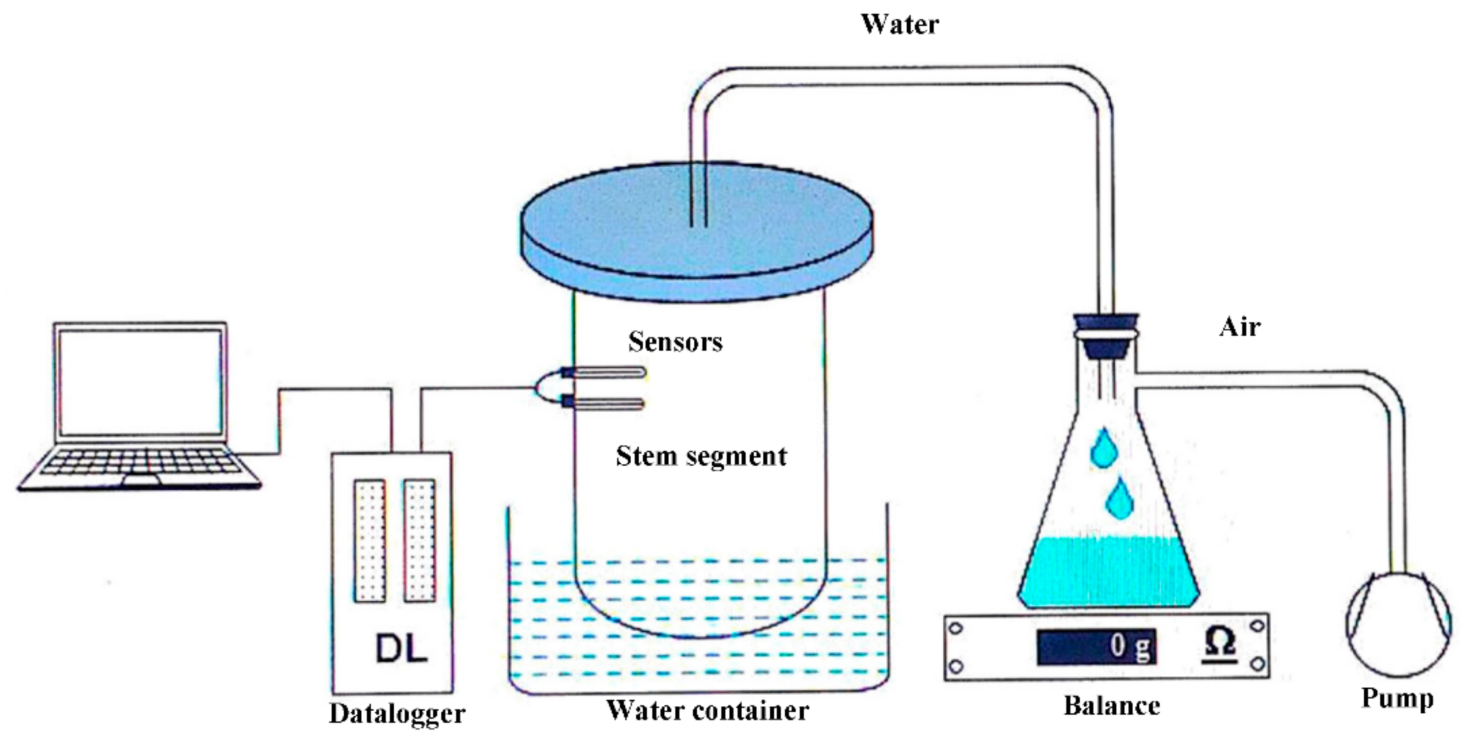

Figure 1. Schematic representation of laboratory calibration of sap flow sensors on date palm stem segment.

Two sensors (Granier type $90 \mathrm{~mm}$ in length and $2 \mathrm{~mm}$ in diameter, PlantSensors, Nakara, NT, Australia) were installed radially in each stem segments. For each sensor, a distance of $5 \mathrm{~cm}$ was maintained between the two probes. Before inserting the probes, aluminum tubes previously filled with silicone grease were inserted into the stem. The temperature differences $(\Delta T)$ were measured each $10 \mathrm{~s}$, and the data were averaged and saved each $2 \mathrm{~min}$, after flow rates were allowed to stabilize ( $25 \mathrm{~min}$ ). The value of $\Delta$ Tmax was obtained from the thermal dissipation sensors by turning off the vacuum pump two-to-three hours after flow measurement was completed. The relationships between temperature differences $\left(\mathrm{K},{ }^{\circ} \mathrm{C}\right)$ over the sap flow density periods $(\Delta T)$ and temperature differences during zero flow ( $\Delta$ Tmax) were studied based on Equation (2). The sensors were connected to a CR1000 datalogger and an AM16/32A multiplexer (Campbell Scientific Inc., Logan, UT, USA) to save data measurements. Ten values of water flow were measured nine times on each date palm stem segment. The $\mathrm{J}_{\mathrm{s}}$ values from the two sensors in each stem segment were averaged, and $\mathrm{K}, \mathrm{J}_{\mathrm{S}}$, and $\mathrm{F}_{\mathrm{S}}$ were calculated for each individual tree using Equations (1)-(3). The data were processed with PC-200W (software, v4.5, Campbell Scientific Ltd., Montrouge, France). The quantity of water pumped every 2 min was considered to be the gravimetric measurement $\left(\mathrm{J}_{\mathrm{g}}\right)$ of the stem over that time period. Calibrations were performed using nonlinear regression of the form $\mathrm{y}=\alpha \mathrm{K}^{\beta}$ to generate new $\alpha$ and $\beta$ parameter values to predict $\mathrm{J}_{\mathrm{g}}$ as a function of $\mathrm{K}$. The relationship between gravimetric $\left(\mathrm{J}_{\mathrm{g}}\right)$ and estimated $\left(\mathrm{J}_{\mathrm{s}}\right)$ sap flow density, was calculated from both the original and the new $\alpha$ and $\beta$ parameter values obtained in the calibration.

\subsection{Conductive Area Determination}

After each flow measurement, $0.1 \%$ of safranin " $\mathrm{O}$ " was pulled over each stem segments for 15-20 min, the conducting area was visually determined by the change in color between active and inactive area. Sections were scanned and the colored area was calculated using Image J software, v2 (National Institutes of Health, Bethesda, MD, USA, https:/ /imagej.nih.gov/ij/ (accessed on 18 April 2021)). From this data, it was possible to make the relationship between sap flow density (Js) (Equation (1)) and the total sap flux $\left(\mathrm{F}_{\mathrm{s}}\right)$ (Equation (3)). 


\subsection{Error Calculations}

For each mean's measured value between gravimetric $\left(\mathrm{J}_{\mathrm{g}}\right)$ and estimated $\left(\mathrm{J}_{\mathrm{s}}\right)$ sap flux density, a measurement of sap flux density percentage error was calculated as follows [46]:

$$
\% \text { Error }=(\text { Gravimetric }- \text { Estimated } / \text { Gravimetric }) \times 100
$$

\subsection{Statistical Analyses}

Regression analyses were fitted using GraphPad Prism (v7.0, San Diego, CA, USA). The Student's $t$-test was used to compare the sap flow density $\left(\mathrm{F}_{\mathrm{d}}\right)$ values obtained from gravimetric $\left(\mathrm{J}_{\mathrm{g}}\right)$ and estimated $\left(\mathrm{J}_{\mathrm{s}}\right)$ measurements.

\section{Results}

\subsection{Calibration Experiment}

Calibration results were significantly $(p<0.001)$ different from the Granier calibration [7] within and between the three cultivars. In the opposition to coefficient $\alpha$ of the Granier equation ( $\left.119 \mathrm{~g} \mathrm{~m}^{-2} \mathrm{~s}^{-1}\right)$, the coefficient $\alpha$ obtained from our measurements ranged from 133.7 to $135.2 \mathrm{~g} \mathrm{~m}^{-2} \mathrm{~s}^{-1}$, whereas values obtained for exponent $\beta$ ranged from 1.517 to 1.677 (Figure 2). The mean coefficient values for sap flow density were $134.5 \mathrm{~g} \mathrm{~m}^{-2}$ $\mathrm{s}^{-1}(\mathrm{SE}=0.16)$ and $1.603(\mathrm{SE}=0.04)$ for $\alpha$ and $\beta$, respectively (Table 2$)$. Low variability across stems was observed for different date palm trees of the same species. Differences between the calibration coefficients and those from the original Granier equation are clearly visible when $\mathrm{J}_{\mathrm{s}}$ is calculated from $\mathrm{K}$ (Figure 3)
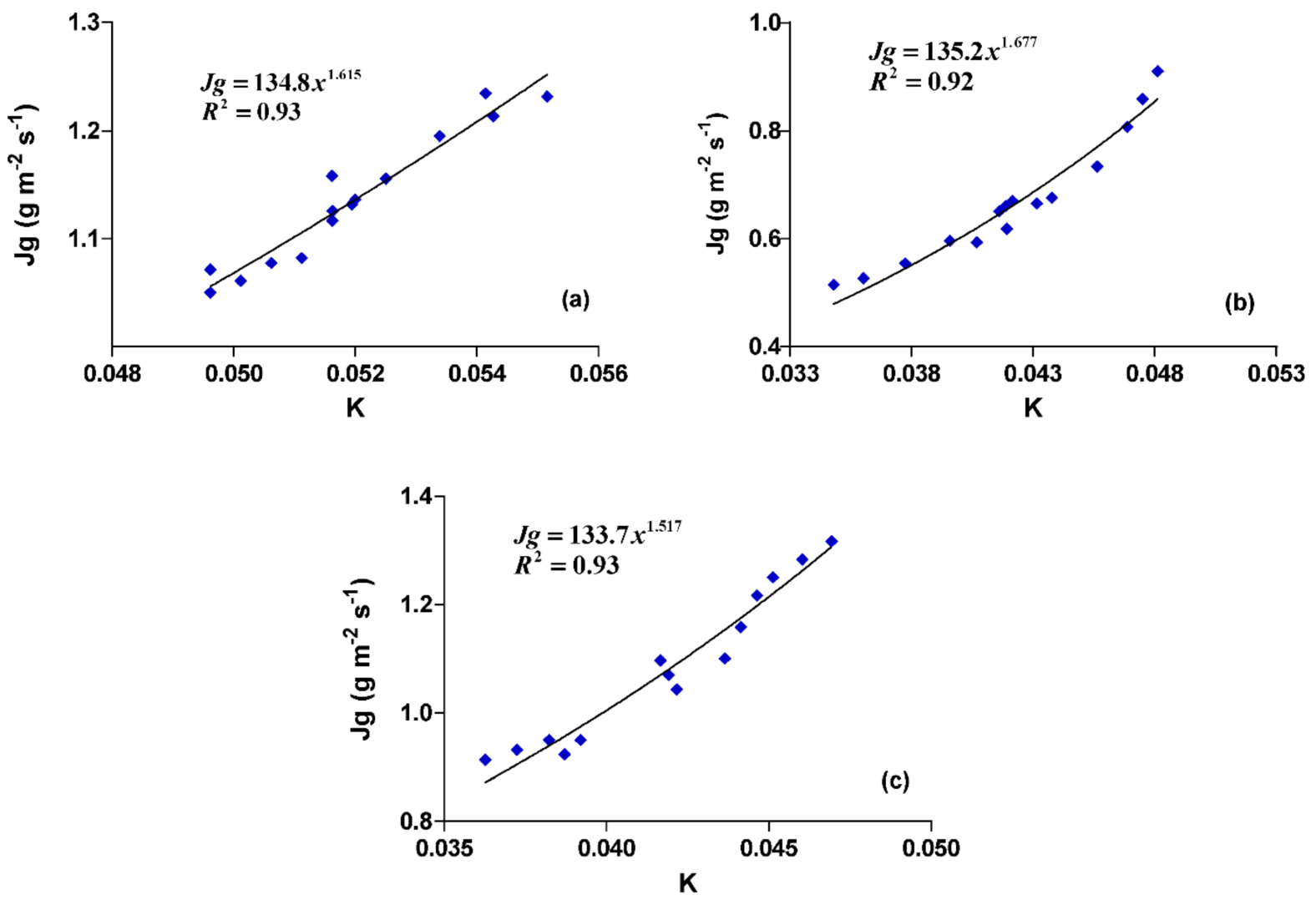

Figure 2. Nonlinear regression $\left(y=a x^{b}\right)$, where $J_{g}$ is the dependent variable, $K$ is the independent variable, $x$, for 'Assiane' (a), 'Khalt' (b) and 'Tadmament' (c) cultivars. Jg was calculated by using the new parameters values derived from gravimetric measurements. 
Table 2. Regression coefficients calibrated for sap flux density measurements.

\begin{tabular}{cccccc}
\hline Cultivars & Conductive Area $\left.\mathbf{( c m}^{\mathbf{2}}\right)$ & Sensors Depth $\mathbf{( c m )}$ & $\boldsymbol{\alpha}\left(\mathbf{g m}^{-\mathbf{2}} \mathbf{s}^{-\mathbf{1}}\right)$ & $\boldsymbol{\beta}$ & $\mathbf{R}^{\mathbf{2}}$ \\
\hline 'Assiane' & $330.66 \pm 13.57$ & 9 & $134.80 \pm 0.66^{* * *}$ & $1.615 \pm 0.02^{* * *}$ & 0.93 \\
'Tadmament' & $302.33 \pm 15.88$ & 9 & $133.70 \pm 0.48^{* * *}$ & $1.517 \pm 0.04^{* * *}$ & 0.93 \\
'Khalt' & $298.00 \pm 26.96$ & 9 & $135.20 \pm 0.51^{* * *}$ & $1.677 \pm 0.03^{* * *}$ & 0.92 \\
Mean & $310.33 \pm 22.96$ & 9 & $134.50 \pm 0.57^{* * *}$ & $1.603 \pm 0.05^{* * *}$ & 0.93 \\
SE & 7.65 & 0 & 0.16 & 0.04 & 0 \\
\hline
\end{tabular}

${ }^{* * *}: p<0.001$ compared to Ganier coefficients.

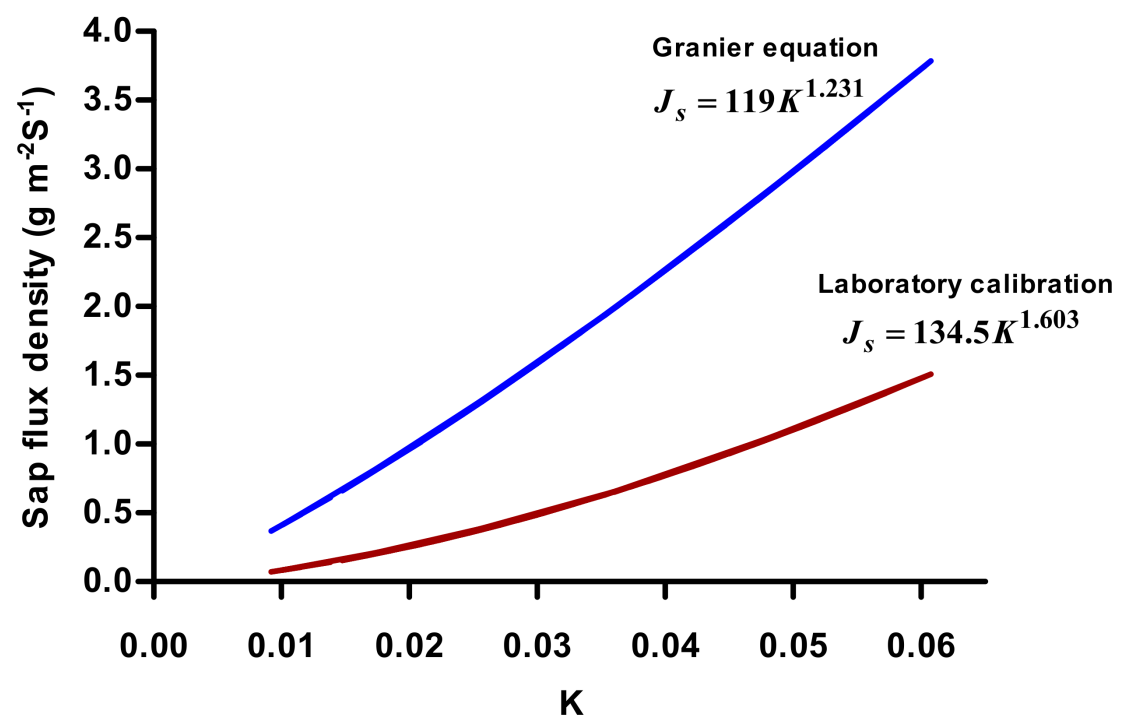

Figure 3. The relationship between sap flux density $\left(\mathrm{J}_{\mathrm{s}}\right)$ and $\mathrm{K}$ estimated by laboratory calibration and Granier equation.

The linear relationship between $\mathrm{J}_{\mathrm{S}}$ values derived from the original parameters (Figure $4 \mathrm{a}$ ) and our new parameters (Figure $4 b$ ) with Jg was strong in both cases $\left(R^{2} \geq 0.9\right)$. However, estimating sap flux using the new parameters improved the accuracy of measurement from an overestimation of $18.2 \pm 0.5 \%$ to a slight underestimation of $1.8 \pm 0.5 \%$.

(a)

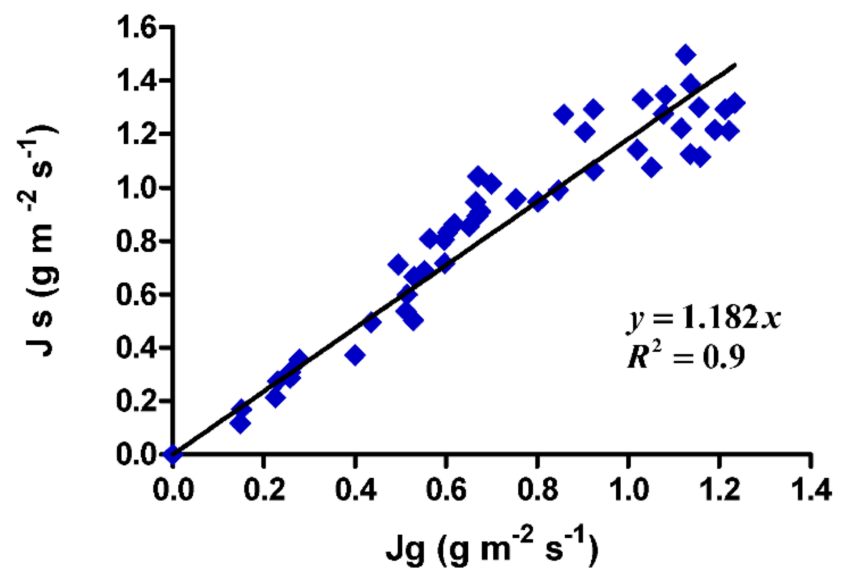

(b)

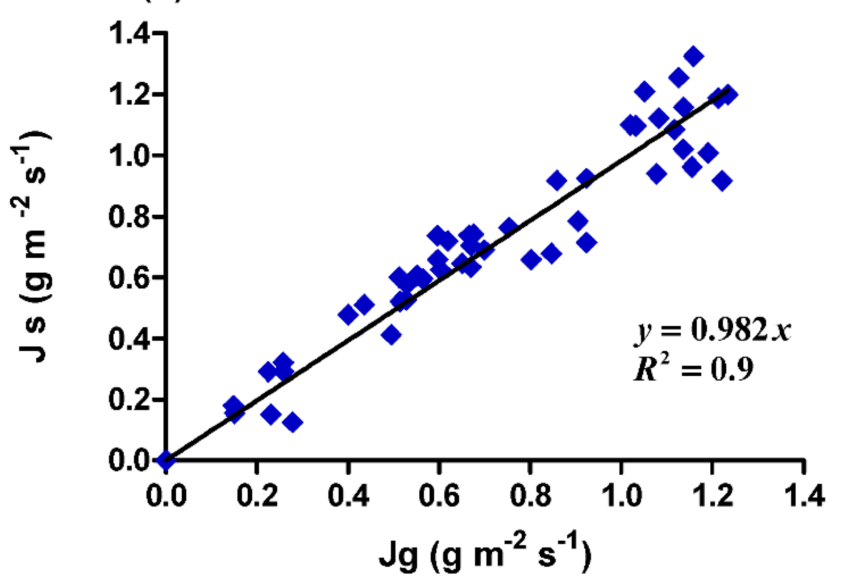

Figure 4. Plot of sap flow densities estimated from gravimetric measurements $\left(\mathrm{J}_{\mathrm{g}}\right)$ versus thermal dissipation probes $\left(\mathrm{J}_{\mathrm{S}}\right)$, by applying both: values defined by the calibration equation (a) and derived by the new parameters $(\mathbf{b})$. 


\subsection{Conductive Area}

The average active conductive area was $330.66 \pm 13.57,302.33 \pm 15.88$, and $298 \pm 26.96 \mathrm{~cm}^{2}$ for "Assiane", "Tadmament" and "Khalt" cultivars, respectively (Table 2). Examples of variations in conductive area, which were used for the calibration method, are illustrated in Figure 5.

a

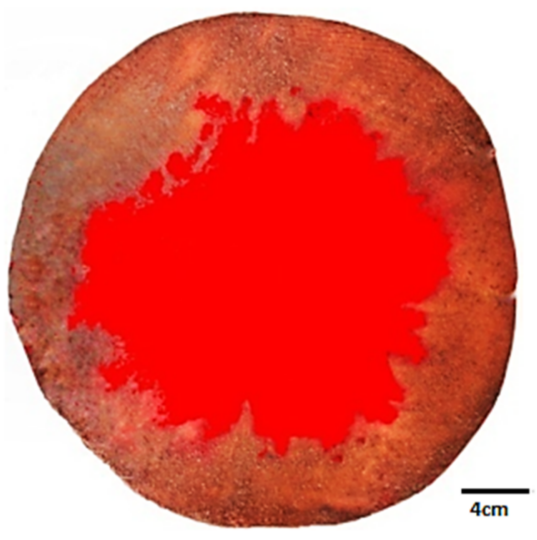

b

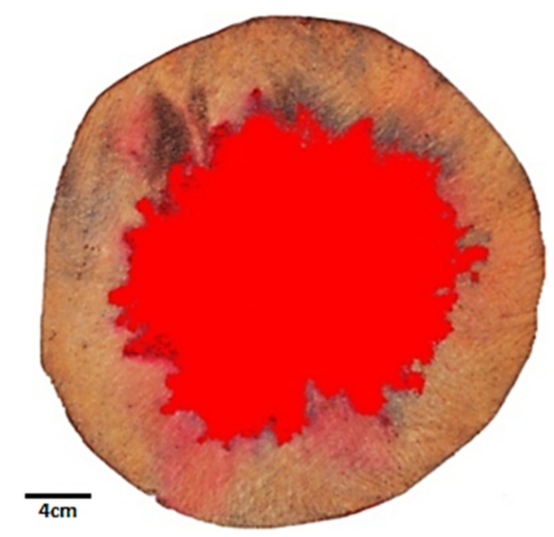

Figure 5. Images of transversal section of the stems. The colored area represents the active conductive area.

The proportion analysis of conductive area shows that $54 \%$ of stem area was colored, and able to conduct water. For all stem segments of all studied cultivars, the active conductive area can represent half of the stem.

\section{Discussion}

There have been a number of studies where Granier calibration equation [7] was evaluated by comparing sap flux densities calculated from Granier's original [7] equation with gravimetric derived values. Table 3 provides a summary of literature on the calibration of the TDP method in various species. Non-contradictory estimations utilizing the original calibration equation [7] have been reported for some species; however, large underestimations/overestimations became apparent for most other species [25]. The accuracy of this technique is critically dependent majorly on assumptions, which do not apply to all species $[5,40]$. The re-calibration results for different species have yielded an alpha parameter which range from 119 [7] over $58,100 \mathrm{~g} \mathrm{~m}^{-2} \mathrm{~s}^{-1}$ for ring-porous temperate tree species [14].Using $\alpha$ and $\beta$ parameter values derived from our study, we improved the sap flux density measurements, from those originally developed by Granier [7]. The discrepancy between gravimetric and TDP sap flux measurements changed from an overestimation of $18.2 \pm 0.5 \%$ to an underestimation of $1.8 \pm 0.5 \%$ when the original parameters of Granier [7] have been used. The average value obtained for $\alpha$ coefficient was $134.5 \mathrm{~g} \mathrm{~m}^{-2} \mathrm{~s}^{-1}$ instead of 119 as found by Granier, whereas the scaling exponent $\beta$ was 1.603. These results show a better agreement with $\alpha$ and $\beta$ parameters values, found by Niu et al. [31] on oil palms (Elaeis guineensis Jacq.)using the same validation methodology. In the same study (Elaeis guineensis Jacq.) [31], actual sap flow was overestimated by $17.3 \%$, when applying the new parameters values derived. For rainforest palms (Iriartea deltoidea Ruiz \& Pav.), Renninger and Phillips [43] have obtained calibration results $(\alpha=192.3, \beta=1.3)$ that differed largely from the Granier equation [7]; however, values yielded from the original equation were not significantly different of those calculated with new calibration equation. In the study by Sperling, et al. [45], a comparison of actual transpiration measured with a weighing lysimeters, to that measured with thermal dissipation probes, revealed an underestimation of $40 \%$ for date palms (Phoenix dactylifera $\mathrm{L}$.). For Cocos nucifera, alpha parameter was also found to be higher $(\alpha=315)$ than the original 
equation, the $\beta$ parameter value being similar ( $\beta=1.231$ ) [42]. Similar underestimations were found when using the original calibration equation, for example, by Steppe et al. [19] with underestimated sap flow by $60 \%$ in Fagus grandifolia, Hultine, et al. [16] found a 50\% underestimate in Tamarix ramosissima $\times$ chinesis, and Paudelet al. [37] in apple (Malus domestica Borkh. cv. Golden delicious) where underestimations of $70 \%$ were recorded. The TDP method has lots of uncertainty $[19,47,48]$. The irregularity in the equation coefficients including the fluctuation in the rate of overestimate sap flow density obtained on the date palm (Phoenix dactylifera $\mathrm{L}$.) can be explained probably by the xylem anatomy (differences in the distribution and diameter of the xylem vessels), or due to high water content in date palm stem. Several studies found that the large variation in their measurements was primarily due to the same error as ours $[14,22,25,30,39]$. There are a number of errors who can be the reason of discrepancies between estimating sap flux density achieved with the Granier's initial equation [7], and that from the new parameters. It includes the physiological aspects such as xylem anatomy [30], sapwood characteristics [21,39], a small conducting sapwood area [25], thermal gradients [20], wounding responses [21,49], and technical aspects such as installations [25], sensor type [14,50,51], probes length [22,52], or other methodological aspects such as the contact of the probes with inactive xylem [22,37,39,53], and calibration set-up [31]. From these results, we concluded that the TPD method [7] should be calibrated for each species where possible.

Table 3. Examples of the calibration of sap flow systems using thermal dissipation method (TDP).

\begin{tabular}{|c|c|c|c|c|c|c|c|}
\hline Reference & Species & Technique & $\begin{array}{l}\text { Calibration } \\
\text { Method }\end{array}$ & $\alpha \mathrm{g} / \mathrm{m}^{3} / \mathrm{s}$ & $\beta$ & $\begin{array}{c}\text { Probes } \\
\text { Lenght }(\mathrm{mm})\end{array}$ & $\begin{array}{c}\text { Stem Diameter } \\
(\mathrm{mm})\end{array}$ \\
\hline [7] & $\begin{array}{l}\text { Pinus nigra, } \\
\text { Pseudotsuga } \\
\text { menziesii, } \\
\text { Quercus } \\
\text { pedunculata }\end{array}$ & TDP & Cut stem & 119 & 1.231 & 20 & $40-50$ \\
\hline [32] & Actinidia deliciosa & TDP & $\begin{array}{l}\text { Cut tree } \\
\text { Potometer }\end{array}$ & $\begin{array}{l}57 \\
63\end{array}$ & - & $\begin{array}{l}10 \\
20\end{array}$ & 10 \\
\hline [30] & Carica papaya & TDP & $\begin{array}{c}\text { Stem } \\
\text { perfusion }\end{array}$ & 1531 & 1.910 & 30 & 55 \\
\hline$[34]$ & $\begin{array}{l}\text { Mangifera indica, } \\
\text { Heveabra siliensis, } \\
\text { Citrus maxima }\end{array}$ & TDP & Cut stem & $\begin{array}{l}772 \\
778 \\
749\end{array}$ & 1.414 & 20 & $\begin{array}{l}43.5 \\
46.8 \\
51.4\end{array}$ \\
\hline [16] & Tamarix spp. & TDP & $\begin{array}{c}\text { Stem } \\
\text { perfusion }\end{array}$ & 240 & 1.16 & 10 & 41.6 \\
\hline [35] & Citrus sinensis & TDP & $\begin{array}{c}\text { Stem } \\
\text { perfusion }\end{array}$ & 594 & 1.231 & 10 & 25 \\
\hline [37] & $\begin{array}{l}\text { Malus domestica, } \\
\text { Prunus persica, } \\
\text { Diospyros kaki }\end{array}$ & TDP & $\begin{array}{c}\text { Stem } \\
\text { perfusion }\end{array}$ & 486 & 1.157 & 20 & $40-50$ \\
\hline [39] & Citrus limon Eureka & TDP & $\begin{array}{c}\text { Stem } \\
\text { perfusion }\end{array}$ & 184 & 1.33 & 30 & 50 \\
\hline [41] & $\begin{array}{l}\text { Eucalyptus grandis } \\
\times \text { urophylla }\end{array}$ & TDP & Cut stem & 304.46 & 1.606 & 20 & 134-145 \\
\hline [42] & Cocos nucifera & TDP & $\begin{array}{c}\text { Stem } \\
\text { perfusion }\end{array}$ & 315 & 1.231 & 20 & 41 \\
\hline [43] & Iriartea deltoidea & TDP & Cut stem & 192.3 & 1.3 & 10 & 50 \\
\hline [31] & Elaeis guineesis Jacq. & TDP & Cut leaves & 134 & 1.6 & 12.5 & - \\
\hline
\end{tabular}




\section{Conclusions}

Thermal dissipation probes [7] are the most widely used for measuring sap flux in trees. Our findings, in addition to reports of other calibrations, have led us to conclude that the original calibration is not universally applicable, and should not be appropriate in all species. Rather, each species may require a unique calibration and unique parameter values. Being a monocot species, date palm structure differs significantly from dicotyledonous wood. The results reported in this study, suggest that stem anatomy of date palm can be a source of errors associated with the thermal dissipation method use. The measurements showed that the stem anatomy led to an overestimation around $18.2 \pm 0.5 \%$, and that use the new specific parameters derived, may allow for a more precise estimation of sap flux density in date palm. From this study, it is clear that the xylem anatomy of the stem will have a large influence on measurements, and this must be taken into account in each new species in which measurements are to be made. However, it is likely that correction parameters will only be valid for the stem size range used in the calibration. Future calibration experiments should address the extent of intraspecific variation in these parameters for stems of different diameter and age.

Supplementary Materials: The following supporting information can be downloaded at: https: / /www.mdpi.com/article/10.3390/horticulturae8020107/s1, Figure S1: palm tree.

Author Contributions: Conceptualization, F.A. and M.A.E.; methodology, K.J. and H.M. (Hanane M'hamdi); investigation and data curation, F.A.; writing-original draft preparation, F.A., M.A.E. and H.M. (Hamza Mechchate); review and editing M.N.A., N.M.A. and O.N.; supervision, J.M. and M.A.E. All authors have read and agreed to the published version of the manuscript.

Funding: This study was funded by the Princess Nourah bint Abdulrahman University Researchers Supporting Project (Grant No. PNURSP2022R103), Princess Nourah bint Abdulrahman University, Riyadh, Saudi Arabia.

Institutional Review Board Statement: Not applicable.

Informed Consent Statement: Not applicable.

Data Availability Statement: Data are available upon request.

Acknowledgments: The authors extend their appreciation to Princess Nourah bint Abdulrahman University Researchers Supporting Project number (Grant No. PNURSP2022R103), Princess Nourah bint Abdulrahman University, Riyadh, Saudi Arabia.

Conflicts of Interest: The authors declare no conflict of interest.

\section{References}

1. Munier, P. Le Palmier-Dattier. Techniques Agricoles et Productions Tropicales; Maisonneuve \& Larose: Paris, France, 1973.

2. FAOSTAT. Agro-Statistics. Database; Food \& Agriculture Organization: Rome, Italy, 2017. Available online: http://www.Fao.Org/ Faostat (accessed on 19 March 2020).

3. Bodian, A.; Elhoumaizi, M.A.; Ndir, K.N.; Hasnoui, A.; Nachtigall, M.; Wehling, P. Genetic diversity analysis of date palm (Phoenix dactylifera L.) cultivars from Figuig oasis (Morocco) using SSR markers. J. Biodivers. Biopros. Dev. 2012, 2, 96-104.

4. FAO. Irrigated date palm production in the Near East. In Proceedings of the Workshop on Irrigation of Date Palm and Associated Crops, Damascus, Syria, 27-30 May 2007; Food and Agriculture Organization of the United Nations: Cairo, Egypt, 2008; pp. 1-15.

5. Smith, D.; Allen, S. Measurement of sap flow in plant stems. J. Exp. Bot. 1996, 47, 1833-1844. [CrossRef]

6. Tfwala, C.; Van Rensburg, L.; Bello, Z.; Green, S. Calibration of compensation heat pulse velocity technique for measuring transpiration of selected indigenous trees using weighing lysimeters. Agric. Water Manag. 2018, 200, 27-33. [CrossRef]

7. Granier, A. A new method for measuring the sap flux in the trunk of trees. Ann. For. Sci. 1985, 42, 193-200. [CrossRef]

8. Granier, A. Evaluation of transpiration in a Douglas-fir stand by means of sap flow measurements. Tree Physiol. 1987, 3, 309-320. [CrossRef]

9. Nadezhdina, N.; Cermak, J.; Nadezhdin, V. Heat field deformation method for sap flow measurements. In Measuring Sap Flow in Intact Plants, Proceedings of the 4th International Workshop; Židlochovice, Czech Republic, 3-5 October 1998, IUFRO Publ.: Vienna, Austria; Mendel University: Brno, Czech Republic, 1998; pp. 72-92.

10. Marshall, D. Measurement of Sap Flow in Conifers by Heat Transport. Plant Physiol. 1958, 33, 385-396. [CrossRef] 
11. Swanson, R.; Whitfield, D. A Numerical Analysis of Heat Pulse Velocity Theory and Practice. J. Exp. Bot. 1981, 32, 221-239. [CrossRef]

12. Čermák, J.; Deml, M.; Penka, M. A new method of sap flow rate determination in trees. Biol. Plant. 1973, 15, 171-178. [CrossRef]

13. Sakuratani, T. A Heat Balance Method for Measuring Water Flux in the Stem of Intact Plants. J. Agric. Meteorol. 1981, 37, 9-17. [CrossRef]

14. Oliveras, I.; Llorens, P. Medium-term sap flux monitoring in a Scots pine stand: Analysis of the operability of the heat dissipation method for hydrological purposes. Tree Physiol. 2001, 21, 473-480. [CrossRef]

15. Sun, H.; Aubrey, D.P.; Teskey, R.O. A simple calibration improved the accuracy of the thermal dissipation technique for sap flow measurements in juvenile trees of six species. Trees 2011, 26, 631-640. [CrossRef]

16. Hultine, K.; Nagler, P.; Morino, K.; Bush, S.; Burtch, K.; Dennison, P.; Glenn, E.; Ehleringer, J. Sap flux-scaled transpiration by tamarisk (Tamarix spp.) before, during and after episodic defoliation by the saltcedar leaf beetle (Diorhabda carinulata). Agric. For. Meteorol. 2010, 150, 1467-1475. [CrossRef]

17. Vergeynst, L. Changes in temperature and stem water content evoke erroneous sap flux density estimates with Thermal Dissipation Probes. In Proceedings of the 8th International Workshop on Sap Flow, Volterra, Italy, 8-12 May 2011.

18. Do, F.; Rocheteau, A. Influence of natural temperature gradients on measurements of xylem sap flow with thermal dissipation probes. 2. Advantages and calibration of a noncontinuous heating system. Tree Physiol. 2002, 22, 649-654. [CrossRef] [PubMed]

19. Steppe, K.; De Pauw, D.J.; Doody, T.M.; Teskey, R.O. A comparison of sap flux density using thermal dissipation, heat pulse velocity and heat field deformation methods. Agric. For. Meteorol. 2010, 150, 1046-1056. [CrossRef]

20. Lu, P.; Urban, L.; Zhao, P. Granier's thermal dissipation probe (TDP) method for measuring sap flow in trees: Theory and practice Acta Bot. Sin. 2004, 46, 631-646.

21. Wullschleger, S.D.; Childs, K.W.; King, A.W.; Hanson, P.J. A model of heat transfer in sapwood and implications for sap flux density measurements using thermal dissipation probes. Tree Physiol. 2011, 31, 669-679. [CrossRef]

22. Clearwater, M.; Meinzer, F.; Andrade, J.L.; Goldstein, G.; Holbrook, N.M. Potential errors in measurement of nonuniform sap flow using heat dissipation probes. Tree Physiol. 1999, 19, 681-687. [CrossRef]

23. Vandegehuchte, M. Measuring Sap Flow and Stem Water Content in Trees: A Critical Analysis and Development of a New Heat Pulse Method (Sapflow+). Ph.D. Thesis, Ghent University, Ghent, Belgium, 2013.

24. Ren, R.; Liu, G.; Wen, M.; Horton, R.; Li, B.; Si, B. The effects of probe misalignment on sap flux density measurements and in situ probe spacing correction methods. Agric. For. Meteorol. 2017, 232, 176-185. [CrossRef]

25. Bush, S.E.; Hultine, K.R.; Sperry, J.S.; Ehleringer, J.R. Calibration of thermal dissipation sap flow probes for ring- and diffuseporous trees. Tree Physiol. 2010, 30, 1545-1554. [CrossRef]

26. Wiedemann, A.; Marañón-Jiménez, S.; Rebmann, C.; Herbst, M.; Cuntz, M. An empirical study of the wound effect on sap flux density measured with thermal dissipation probes. Tree Physiol. 2016, 36, 1471-1484. [CrossRef]

27. Poyatos, R.; Granda, V.; Molowny-Horas, R.; Mencuccini, M.; Steppe, K.; Martinez-Vilalta, J. SAPFLUXNET: Towards a global database of sap flow measurements. Tree Physiol. 2016, 36, 1449-1455. [CrossRef] [PubMed]

28. Lu, P.; Woo, K.; Liu, Z. Estimation of whole-plant transpiration of bananas using sap flow measurements. J. Exp. Bot. 2002, 53, 1771-1779. [CrossRef] [PubMed]

29. Liu, H.-J.; Cohen, S.; Tanny, J.; Lemcoff, J.H.; Huang, G. Transpiration estimation of banana (Musa sp.) plants with the thermal dissipation method. Plant Soil 2008, 308, 227-238. [CrossRef]

30. Fabrício, D.O.R.; Eliemar, C.; Sousa, D.E.F.; Silva, M.G.E. Sap flow in papaya plants: Laboratory calibrations and relationships with gas exchanges under field conditions. Sci. Hortic. 2006, 110, 254-259.

31. Niu, F.; Röll, A.; Hardanto, A.; Meijide, A.; Köhler, M.; Hendrayanto; Hölscher, D. Oil palm water use: Calibration of a sap flux method and a field measurement scheme. Tree Physiol. 2015, 35, 563-573. [CrossRef]

32. Silva, R.; Paço, T.; Ferreira, M.; Oliveira, M. Transpiration of a kiwifruit orchard estimated using the granier sap flow method calibrated under field conditions. Acta Hortic. 2008, 792, 593-600. [CrossRef]

33. Conceição, N.; Ferreira, M. Combination of sap flow and eddy covariance techniques to obtain long term transpiration in a pear orchard. In VII International Workshop on Sap Flow 846; International Society for Horticultural Science: Leuven, Belgium, 2008; pp. 53-60.

34. Na Ayutthaya, S.I.; Do, F.; Pannengpetch, K.; Junjittakarn, J.; Maeght, J.-L.; Rocheteau, A.; Cochard, H. Transient thermal dissipation method of xylem sap flow measurement: Multi-species calibration and field evaluation. Tree Physiol. 2009, 30, 139-148. [CrossRef]

35. Rubens, D.C.; Lucas, M.V.; Eusimio, F.F.J. Estimation of transpiration of the 'Valencia' orange young plant using thermal dissipation probe method. Eng. Agric. 2012, 32, 573-581.

36. Zhao, P.; Mei, T.-T.; Ni, G.-Y.; Yu, M.-H.; Zeng, X.-P. Application of thermal dissipation probe in the study of Bambusa chungii sap flow. J. Appl. Ecol. 2012, 23, 979-984.

37. Paudel, I.; Kanety, T.; Cohen, S. Inactive xylem can explain differences in calibration factors for thermal dissipation probe sap flow measurements. Tree Physiol. 2013, 33, 986-1001. [CrossRef]

38. Miner, G.L.; Hama, J.M.; Kluitenberg, G.J. A heat-pulse method for measuring sap flow in corn and sunflower using 3D-printed sensor bodies and low-cost electronics. Agric. For. Meteorol. 2017, 246, 86-97. [CrossRef] 
39. Sam, M.C. Calibration of Sap Flow Techniques in Citrus Using the Stem Perfusion Method. Ph.D. Thesis, University of Pretoria, Pretoria, South Africa, 2016.

40. Hubbard, R.M.; Stape, J.; Ryan, M.; Almeida, A.C.; Rojas, J. Effects of irrigation on water use and water use efficiency in two fast growing Eucalyptus plantations. For. Ecol. Manag. 2010, 259, 1714-1721. [CrossRef]

41. Gao, J.; Zhou, J.; Sun, Z.; Niu, J.; Zhou, C.; Gu, D.; Huang, Y.; Zhao, P. Suppression of nighttime sap flux with lower stem photosynthesis in Eucalyptus trees. Int. J. Biometeorol. 2015, 60, 545-556. [CrossRef] [PubMed]

42. Roupsard, O.; Bonnefond, J.-M.; Irvine, M.; Berbigier, P.; Nouvellon, Y.; Dauzat, J.; Taga, S.; Hamel, O.; Jourdan, C.; Saint-André, L.; et al. Partitioning energy and evapo-transpiration above and below a tropical palm canopy. Agric. For. Meteorol. 2006, 139, 252-268. [CrossRef]

43. Renninger, H.J.; Phillips, N. Intrinsic and extrinsic hydraulic factors in varying sizes of two Amazonian palm species (Iriartea deltoidea and Mauritia flexuosa) differing in development and growing environment. Am. J. Bot. 2010, 97, 1926-1936. [CrossRef] [PubMed]

44. Sellami, M.H.; Sifaoui, M.S. Estimating transpiration in an intercropping system: Measuring sap flow inside the oasis. Agric. Water Manag. 2003, 59, 191-204. [CrossRef]

45. Sperling, O.; Shapira, O.; Cohen, S.; Tripler, E.; Schwartz, A.; Lazarovitch, N. Estimating sap flux densities in date palm trees using the heat dissipation method and weighing lysimeters. Tree Physiol. 2012, 32, 1171-1178. [CrossRef]

46. Reyes-Acosta, J.L.; Vandegehuchte, M.W.; Steppe, K.; Lubczynski, M.W. Novel, cyclic heat dissipation method for the correction of natural temperature gradients in sap flow measurements. Part 2. Laboratory validation. Tree Physiol. 2012, 32, 913-929. [CrossRef]

47. Tatarinov, F.A.; Kucera, J.; Cienciala, E. The analysis of physical background of tree sap flow measurement based on thermal methods. Meas. Sci. Technol. 2005, 5, 1157-1169. [CrossRef]

48. Moore, G.W.; Bond, B.J.; Jones, J.A.; Meinzer, F.C. Thermal-dissipation sap flow sensors may not yield consistent sap-flux estimates over multiple years. J. Tree Sci. 2010, 1, 165-174. [CrossRef]

49. Hogg, E.H.; Artog, G.D.; Black, T.A.; Yang, P.C.; Nesic, Z.; Zimmermann, R.; Neumann, H.H.; Blanken, P.D.; Hurdle, P.A.; Oren, R.; et al. Comparison of sap flow and eddy fluxes of water vapor from a boreal deciduous forest. J. Geophys. Res. Atmos. 1997, 102, 28929-28937. [CrossRef]

50. Wilson, K.B.; Hanson, P.J.; Mulholland, P.J.; Baldocchi, D.D.; Wullschleger, S.D. A comparison of methods for determining forest evapotranspiration and its components: Sap-flow, soil water budget, eddy covariance and catchment water balance. Agric. For Meteorol. 2001, 106, 153-168. [CrossRef]

51. Gutiérrez, M.V.; Santiago, L.S. A comparison of sap flow measurements and potometry in two tropical lowland tree species with contrasting wood properties. Rev. Biol. Trop. 2014, 54, 73-81. [CrossRef] [PubMed]

52. Fuchs, S.; Leuschner, C.; Link, R.M.; Coners, H.; Schuldt, B. Calibration and comparison of thermal dissipation, heat ratio and heat field deformation sap flow probes for diffuse-porous trees. Agric. For. Meteorol. 2017, 244, 151-161. [CrossRef]

53. Pearsall, K.R.; Williams, L.E.; Castorani, S.; Bleby, T.M.; McElrone, A.J. Evaluating the potential of a novel dual heat-pulse sensor to measure volumetric water use in grapevines under a range of flow conditions. Funct. Plant Biol. 2014, 41, 874-883. [CrossRef] 